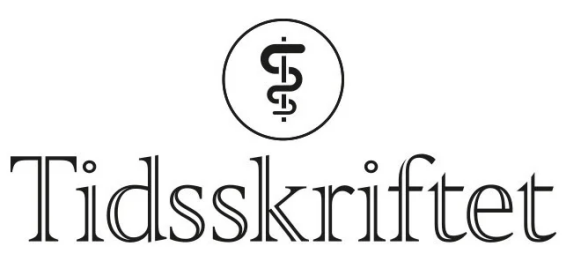

DEN NORSKE LEGEFORENING

\title{
Mann i 6o-årene med tungpustethet og ødemer
}

NOE Å LARE AV

\section{GURI GRIMNES}

guri.grimnes@unn.no

Endokrinologisk seksjon

Universitetssykehuset Nord-Norge

og

Universitetet i Troms $\emptyset$ - Norges arktiske universitet

Guri Grimnes er spesialist i endokrinologi, overlege og førsteamanuensis.

Forfatteren har fylt ut ICMJE-skjemaet og oppgir ingen interessekonflikter.

\section{JOHAN SVARTBERG}

Endokrinologisk seksjon

Universitetssykehuset Nord-Norge

og

Universitetet i Troms $\emptyset$ - Norges arktiske universitet

Johan Svartberg er spesialist i endokrinologi, seksjonsoverlege og professor.

Forfatteren har fylt ut ICMJE-skjemaet og oppgir ingen interessekonflikter.

\section{RAGNAR MARTIN JOAKIMSEN}

Endokrinologisk seksjon

Universitetssykehuset i Nord-Norge

og

Universitetet i Troms $\emptyset$ - Norges arktiske universitet

Ragnar Martin Joakimsen er spesialist i endokrinologi og i nyresykdommer, overlege og professor.

Forfatteren har fylt ut ICMJE-skjemaet og oppgir ingen interessekonflikter.

\section{INA BEATE OLSEN}

Lungemedisinsk avdeling

Universitetssykehuset Nord-Norge

Ina Beate Olsen er spesialist i lungemedisin og overlege.

Forfatteren har fylt ut ICMJE-skjemaet og oppgir ingen interessekonflikter.

\section{GUNNAR OLTMANNS}

Abdomenseksjonen

Røntgenavdelingen

Universitetssykehuset Nord-Norge

og

Universitetet i Troms $\emptyset$ - Norges arktiske universitet

Gunnar Oltmanns er spesialist i radiologi, overlege og universitetslektor.

Forfatteren har fylt ut ICMJE-skjemaet og oppgir ingen interessekonflikter. 
Gastrokirurgisk avdeling Universitetssykehuset Nord-Norge

Eirik Kjus Aahlin er spesialist i generell kirurgi og i gastroenterologisk kirurgi og er overlege. Forfatteren har fylt ut ICMJE-skjemaet og oppgir ingen interessekonflikter.

\section{LINE MOI}

Avdeling for klinisk patologi

Universitetssykehuset Nord-Norge

Line Moi er spesialist i patologi og overlege.

Forfatteren har fylt ut ICMJE-skjemaet og oppgir ingen interessekonflikter.

\section{En mann i 6o-årene ble innlagt med ødemer, tungpustethet og hypertensjon. Det var starten på et langtrukkent og uvanlig sykdomsforløp med diagnostiske og behandlingsmessige utfordringer.}

En mann i 6o-årene med kjent astma, kronisk obstruktiv lungesykdom og seboreisk eksem ble under en ferie innlagt $i$ sykehus grunnet økende hevelse i ansiktet og underekstremitetene samt dyspné som hadde vart noen uker. Han sto på tiotropiumbromid, montelukast og simvastatin, og hadde brukt betametasonsalve inntil for to måneder siden. Han hadde røykt cirka én pakke tobakk per uke, men sluttet fire år før det aktuelle. Gjennom flere år hadde han merket redusert muskelkraft, mer irritabelt humør, økende bukomfang og tendens til blåmerker.

Klinisk undersøkelse viste at pasienten var afebril, med blodtrykk 195/118 mm Hg, respirasjonsfrekvens 24 per minutt, regelmessig puls på 96 slag/min og $\mathrm{SaO}_{2} 94 \%$. Vekten var $81 \mathrm{~kg}$, mot selvoppgitt $71 \mathrm{~kg}$ to måneder tidligere. Han hadde generalisert ødem, proksimal myopati og rundt ansikt, men ikke fettansamling i nakken eller striae.

Hematologiske blodprøver viste normale funn, CRP $13 \mathrm{mg} / \mathrm{l}$ (referanseverdi $<5$ ), glukose 11,2 $\mathrm{mmol} / \mathrm{l}$

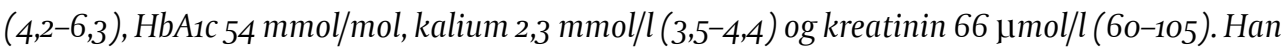
hadde lett troponin T-stigning med 69-57 ng/l $(<15)$ og normale proBNP-verdier. EKG viste sinusrytme med negativ $T$ i nedreveggsavledninger og ST-depresjoner $i V_{3}-V 6$. Ekkokardiografi viste ejeksjonsfraksjon 55 \% og mulig lett nedsatt kontraktilitet i septum basalt. CT thorax viste ingen tegn til lungeemboli. CT abdomen og bekken viste betydelig økt tetthet $i$ krøset, som ga mistanke om pannikulitt eller pankreatittsekvele med fettvevsnekrose.

Ved akuttinnleggelse på grunn av dyspné og ødemer er det flere tilstander som må vurderes, inkludert hjertesvikt og lungeemboli. Man fant etter initial utredning ikke holdepunkter for dette. Symptomer og funn ga mistanke om hyperkortisolisme.

Hormonblodprøver viste morgenkortisol $1620 \mathrm{nmol} / \mathrm{l}$ (130-6oo), adrenokortikotropt hormon (ACTH) 9,6 pmol/l (2,0-11,4), tyreoideastimulerende hormon (TSH) o,24 mIE/l (o,2-4,3), fritt tyroksin ( $\left.F T_{4}\right)$ $7 \mathrm{pmol} / \mathrm{l}$ (9-22), follikkelstimulerende hormon (FSH) 4,6 IU/l (<12), luteiniserende hormon (LH) 1,5 $I U / l(<9)$, testosteron 2,3 $\mathrm{nmol} / \mathrm{l}(10-28)$, seksualhormonbindende globulin (SHBG) $24 \mathrm{nmol} / \mathrm{l} \mathrm{og}$ prolaktin $170 \mathrm{mIU} / \mathrm{l}(86-324)$. Kortisolnivået på kvelden var $1270 \mathrm{nmol} / \mathrm{l}$.

Sammen med det kliniske bildet ga forhøyet kortisol uten døgnvariasjon og ACTH i øvre normalområde mistanke om ACTH-avhengig Cushings syndrom. Slike verdier kan imidlertid også ses som fysiologisk respons på en akutt sykdom. Figur 1 viser kroppens regulering av kortisolproduksjon. 


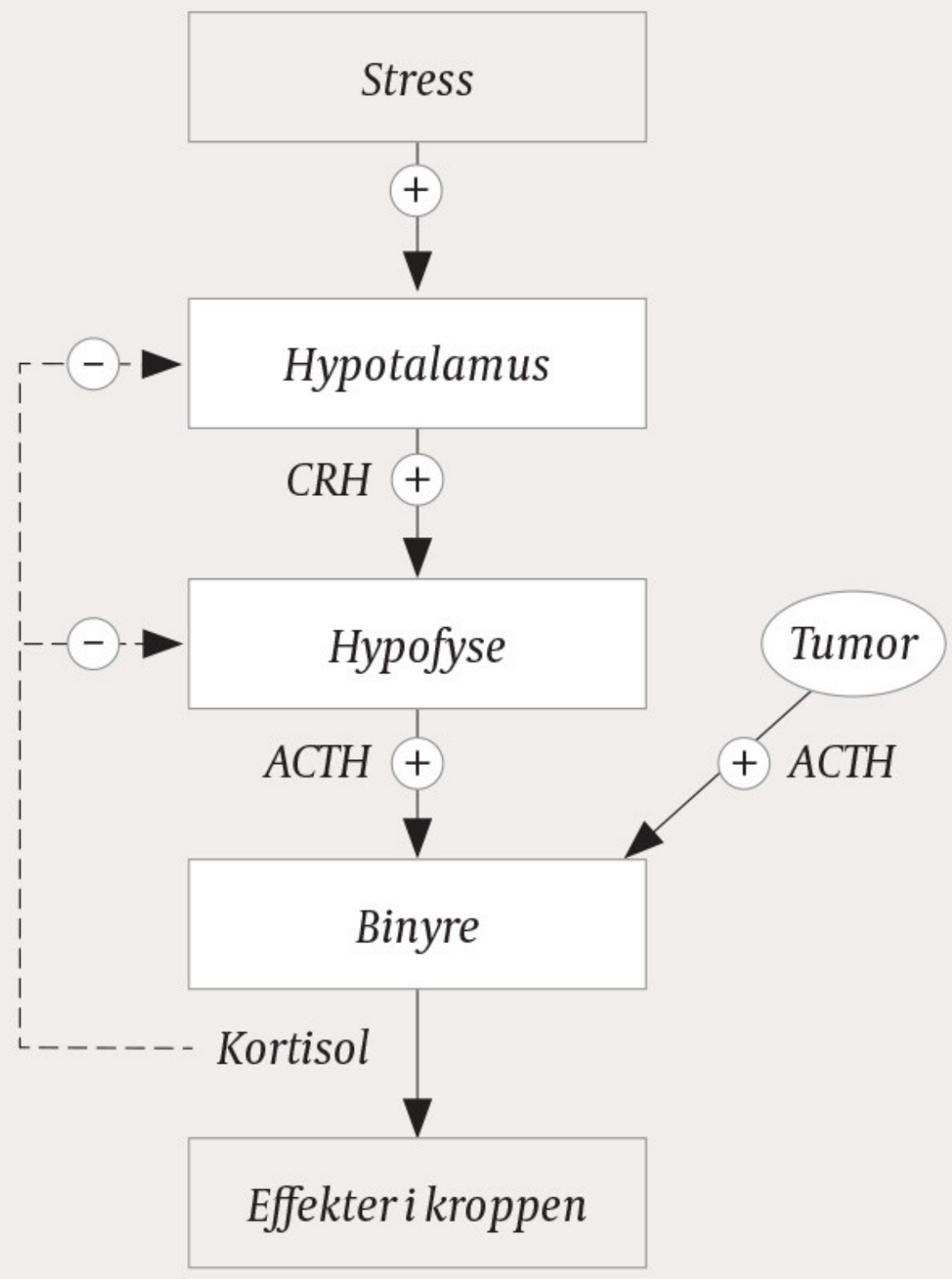

Figur 1 Regulering av kortisolutskilling

Det ble utført kort deksametason-suppresjonstest ramme 1) ((1), hvor morgenkortisol var 1050 nmol/l, dvs. upåvirket.

\section{Ramme 1 Utredning ved Cushings syndrom (1)}

\section{Primærutredning ved mistanke om Cushings syndrom}

- a) Kort deksametason-suppresjonstest: 1 mg deksametason gis kl 23. Neste morgen kl. 8 måles kortisol, som skal være supprimert (<50 nmol/l). Falskt høy verdi kan ses ved

- rask nedbryting av deksametason, f.eks. ved enzyminduksjon grunnet annen medikasjon (fenytoin, karbamazepin, glitazoner)

- $\quad$ kt kortisolbindende globulin på grunn av østrogentilskudd/p-piller

- b) Døgnurinsamling med måling av fritt kortisol. Feilkilder:

- ufullstendig samling (falskt lav verdi) 
- stort urinvolum (falskt høy verdi)

- alvorlig stress, akutt sykdom, depresjoner, fedme, polycystisk ovariesyndrom

(falskt høy verdi)

- nyresvikt (GFR<30 ml/min) (falskt lav verdi)

- c) Spyttkortisol kveld. Falskt forhøyet verdi kan ses ved:

- Blodtilblanding fra munnslimhinne

- Unormal døgnrytme

\section{Videre utredning etter påvist Cushings syndrom}

Ved videre utredning skal man skille ACTH-avhengig fra ACTH-uavhengig Cushings syndrom. ACTH måles på morgenen kl. 8-9:

- $\mathrm{ACTH}>4,4 \mathrm{pmol} / \mathrm{l}=\mathrm{ACTH}$-avhengig

- $\mathrm{ACTH}<2,0 \mathrm{pmol} / \mathrm{l}=\mathrm{ACTH}$-uavhengig

- $\mathrm{ACTH} 2,0-4,4 \mathrm{pmol} / \mathrm{l}=$ gråsone

\section{Videre utredning ved ACTH-avhengig Cushings syndrom}

Ektopisk ACTH-overproduksjon skal skilles fra ACTH-produserende hypofysetumor. Dette er basert på at en hypofysetumor til en viss grad lar seg påvirke av sedvanlige

reguleringsmekanismer.

- Utvidet deksametason-suppresjonstest: Deksametason $0,5 \mathrm{mg} \times 4$ gis over to dager, og serum-kortisol måles påfølgende morgen. Kortisol forventes å falle minst 30 \% ved ACTH-produserende hypofysetumor.

- CRH-test: $100 \mu g$ kortikotropinfrigjørende hormon(CRH) injiseres, og s-kortisol og ACTH måles før injeksjon og etter 15 og 30 minutter. En ACTH-produserende hypofysetumor responderer på dette med stigning i nivåer av ACTH og kortisol, hvor kortisol forventes å stige minst $20 \%$ ved ACTH-produserende hypofysetumor.

Suppresjonstesten styrket mistanken om Cushings syndrom. Med så pass høye ACTHverdier er autonom produksjon i binyre utelukket, men det vil være usikkert om det er hypofysetumor eller ektopisk produksjon som har forårsaket verdiene. Nærmere avklaring baseres på at en ACTH-produserende hypofysetumor til en viss grad lar seg påvirke av sedvanlige reguleringsmekanismer (ramme 1).

Det ble gjort deksametason-suppresjonstest over to døgn og CRH-test, uten at kortisol- eller ACTHverdiene endret seg. MR hypofyse viste normale funn.

Pasienten hadde også påvirkning av flere hypofyseakser, med lav testosteronverdi sammen med lave gonadotropinverdier (hypogonadotrop hypogonadisme) samt lav TSH-verdi sammen med lav $\mathrm{FT}_{4}$-verdi (sekundær hypotyreose). Begge kunne peke mot hypofysær sykdom, hvor manglende stimulering fra hypofysen medfører svekket hormonproduksjon i endeorganene testikler og tyreoidea. Imidlertid kan alvorlig sykdom gi suppresjon av gonadotrop akse (1), og tyreoideaprøvene kunne passe med ikke-tyreoidal sykdom (ㅁ).

Parallelt med primærutredningen ble pasienten satt på behandling for hypertensjon, hypokalemi og hyperglykemi i form av spironolakton, amlodipin, kaliumklorid og insulin. Samlet ga resultatene mistanke om ektopisk Cushings syndrom, og han ble etter seks dager overflyttet til sitt lokale universitetssykehus for videre utredning. Allmenntilstanden var da betydelig bedre.

Ny CT thorax og abdomen ble tatt ti dager etter forrige CT. Igjen fant man en $10 \times 15 \mathrm{~cm}$ stor oppfylning i mesenteriet. Ved biopsi fra oppfylningen ble det kun påvist bindevev og områder med muciner. Det var ikke påvisbare celler i rutinefarget snitt. Immunhistokjemiske undersøkelser var negative for de nevroendokrine markørene kromogranin, synaptofysin og CD56 samt epitelmarkøren cytokeratin (CK). Det var usikkert om biopsimaterialet var representativt. Karsinoembryonalt antigen (CEA) og glykoproteinet CA125 i serum var begge normale. Samlet sett oppfattet vi oppfylningen som mulig fettvevsnekrose. 
Regranskning av de to tidligere CT-undersøkelsene viste en rund kontrastladende kaviterende fortetning på $16 \mathrm{~mm}$ (figur 2) i venstre underlapp ncer øsofagus. Transøsofageal ultralyd med finnålsaspirasjonscytologi påviste noen få grupper tettliggende celler med tydelige cellegrenser, lite cytoplasma og kjerner med lett kornet kromatin uten tydelig nukleol. Cellene ble oppfattet som lett atypiske, men av uviss opprinnelse. I tillegg inneholdt prøven regelmessige plateepitelceller og sannsynlig reaktivt sylinderepitel, antatt fra stikkanal gjennom øsofagus og lunge. Materialet var for sparsomt for immunhistokjemiske undersøkelser.

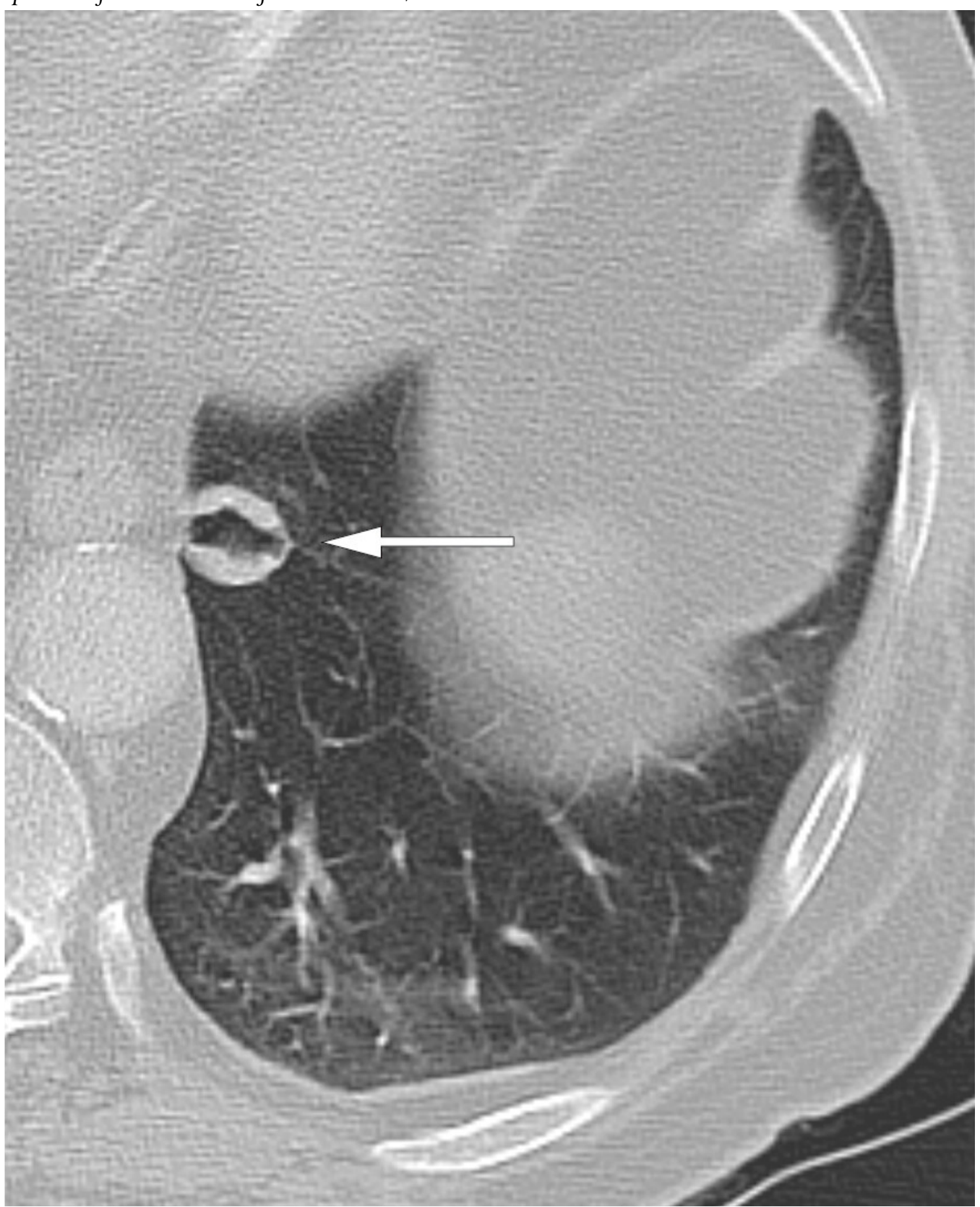

Figur 2 Aksial rekonstruksjon av CT-undersøkelse med intravenøs kontrast og

lungeemboliprotokoll tatt ved første innleggelse. Hes ses lungetumor (markert) medialt basalt i venstre underlapp. Lungetumor er kaviterende, med fortykket vegg med bløtvevstetthet 40-50 HU.

To uker etter finnålsaspirasjonscytologien ble det ble gjort positronemisjonstomografi (PET) med fluorodeoksyglukose (FDG) og CT som viste økt opptak av fluorodeoksyglukose i distale deler av øsofagus samt i lungeforandringen. Opptaket kunne skyldes gjennomgått prosedyre, og man planla derfor gjentatt undersøkelse etter 5-6 uker. Pasienten var imidlertid blitt dårligere, og man startet behandling med ketokonazol.

Medikamentell behandling av hyperkortisolisme baserer seg på hemming av forskjellige ledd i steroidsyntesen. Ketokonazol hemmer flere enzymer i steroidsyntesen, har langsomt innsettende effekt og kan gi blant annet gynekomasti og levertoksisitet. Metyrapon gir 
raskere effekt og hemmer kun siste trinn av kortisolsyntesen. Samtidig øker nivåene av binyreandrogener, som kan gi hirsutisme hos kvinner. Etomidate har også rask effekt og administreres intravenøst. Dette brukes som anestesimiddel, kan gi sedasjon og krever at pasienten blir overvåket. Vårt valg var pragmatisk basert på hva som var tilgjengelig innen rimelig tid.

Tre uker senere ble pasienten innlagt med buksmerter, kvalme og oppkast. Han hadde utspilt buk med palpasjonssmerter i epigastriet, normale tarmlyder og høye inflammasjonsmarkører. Det ble startet behandling med cefotaksim mot infeksjon uten sikkert fokus. CT abdomen viste voksende oppfylning som nå strakk seg fra mesenteriet og opp til pankreas og duodenum. CRP steg til $443 \mathrm{mg} / \mathrm{l}$, og antibiotika ble endret til piperacillin/tazobaktam. Blodkulturene var negative. Han var vedvarende afebril, men samtidig immunsupprimert pga. steroidoverproduksjon. På vital indikasjon ble det utført laparotomi. Man fant en stor abscess og nekrotisk vev, som ved nekrotiserende pankreatitt. Abscesshulen ble tømt og dren innlagt.

Etter hvert tømte det seg gallelignende vaske i drenene, og man mistenkte tynntarmsperforasjon. Det ble gjort gastroskopi, uten tegn til perforasjon av duodenum, men ved reoperasjon fant man en perforasjon helt mot Treitz' ligament. Denne ble lukket. Kromogranin A-verdien var lett forhøyet, på $10 \mathrm{nmol} / \mathrm{l}(<6)$. Ny FDG-PET/CT ble utført, og det ble ikke sett økt FDG-opptak knyttet til lungetumor/ øsofagus, som ved første undersøkelse. Oktreotidscintigrafi avdekket heller ikke patologisk akkumulasjon av somatostatinreseptorpositivt vev.

Utredningen så langt viste ikke entydig at det forelå en ACTH-produserende lungetumor. Kromogranin A-verdien, som er $ø$ kt ved de fleste nevroendokrine tumorer, var lett forhøyet. Imidlertid var prøven tatt etter at pasienten hadde begynt med protonpumpehemmer, hvilket kan gi falskt forhøyede verdier. Dessverre ble det ikke fanget opp at pasientens glukosenivå var forhøyet ved den andre FDG-PET-undersøkelsen, noe som øker risikoen for falskt negative funn.

Pasienten kom seg greit etter operasjonen og ble utskrevet til opptrening på sykehjem. Behandling med ketokonazol ble etter hvert endret til metyrapon, da det lot seg skaffe. Han kom seg raskt under rehabiliteringsoppholdet, og allmenntilstanden var betydelig bedre da han en måned senere ble innlagt for ny evaluering. Denne gangen hadde han morgenkortisol på $755 \mathrm{nmol} / \mathrm{l}$ (ACTH 18,7 pmol/l) og kveldsverdi $393 \mathrm{nmol} / \mathrm{l}$ (ACTH 11,2 pmol/l). Kortisolverdien falt til $140 \mathrm{nmol} / \mathrm{l}$ etter kort deksametason-suppresjonstest. Døgnurinmåling viste fritt kortisol på $267 \mathrm{nmol} / 24 t\left(45^{-272} \mathrm{nmol} / 24\right.$ t).

Vi tolket tendensen til normalisering av kortisolverdiene til at det hele hadde vært en fysiologisk respons på interkurrent sykdom. Mistanken om at det fortsatt kunne foreligge en ACTH-produserende tumor, var dermed svekket.

Behandlingen med metyrapon, spironolakton og amlodipin ble avsluttet. Pasienten fikk opptrening og gjeninnhentet gradvis vekt og muskulatur. Fire måneder etter operasjonen var blodtrykket normalt uten medikasjon og vekten $68 \mathrm{~kg}$. Ytterligere 12 måneder etter dette var klinisk status tilfredsstillende, og morgenkortisol $266 \mathrm{nmol} / \mathrm{l}$. Oppfølgingen ved endokrinologisk poliklinikk ble da avsluttet.

Ytterligere to år senere ble det på kontroll hos lungelege bemerket økende sentral fedme, og det ble målt kortisol kl. 14, som var $750 \mathrm{nmol} / \mathrm{l}$. Han ble innlagt for ny endokrinologisk utredning. Her kom det frem at han det siste halvåret på nytt var blitt hoven $i$ ansiktet, fikk lettere blåmerker og var mer urolig. Han hadde hypertensjon, $160 / 105 \mathrm{~mm} \mathrm{Hg}$, rundt ansikt og sentral fedme med tynne ekstremiteter. Bentetthetsmåling avdekket osteopeni med T-skår-1,9 i lårhalser. Kortisolverdiene var $437 \mathrm{nmol} / \mathrm{l}$ morgen og $529 \mathrm{nmol} / \mathrm{l}$ kveld, med korresponderende ACTH-verdier 17,4 og 16,7 pmol/l. Kveldsverdiene for kortisol i spytt var forhøyet, og kortisol ble ikke supprimert verken etter kort eller lang deksametason-suppresjonstest. Døgnurinsamlingen viste fortsatt normal mengde fritt kortisol, og MR hypofyse viste normale funn. CT avdekket cystiske forandringer i pankreas med utvidelse av pankreasgang, og tumoren i venstre lunges underlapp målte $17 \mathrm{~mm}$ og var blitt mer homogen. Tumor ble beskrevet å ha bred tilfesting til pleura og kunne vere pleural. CT-funnet i pankreas ble vurdert til ikke å vcere malignitetssuspekt, og kontroll med magnetisk resonanskolangiopankreatografi (MRCP) ble planlagt seks måneder frem i tid. 
Ved regranskning av bildene fant man imidlertid en hypervaskulcer lesjon $i$ colon ascendens som kunne vare forenlig med nevroendokrin tumor (NET). Parallelt kom prøvesvarene at progastrinfrigjørende peptid (proGRP) var $4053 \mathrm{ng} / \mathrm{l}(<8$ o ng/l) og nevronspesifikk enolase (NSE) 9,5 $\mu g / l(<12 \mu g / l)$.

På nytt forelå mistanke om ektopisk Cushings syndrom. Forhøyet proGRP styrket mistanke om tumor med nevroendokrin differensiering, men siden lungelesjonen var tilnærmet uendret over tre år, FDG-opptak ikke var økt på siste FDG-PET/CT eller var synlig på oktreotidscintigrafi, og finnålsaspirasjonscytologi tidligere var gjort, ville vi avvente resultatene fra planlagt koloskopivurdering før ny lungeutredning.

Ved koloskopiundersøkelse gjenfant man ingen tumor i colon ascendens, men små polypper lenger distalt. Histologi viste tubulcere adenomer med lavgradig intraepitelial neoplasi. Kromogranin Averdien var nå 5,6 nmol/l (endret ref. <3,5). Ny oktreotidscintigrafi var negativ. Før planlagt lungeutredning ble pasienten innlagt med muskelsvakhet, generell hevelse og psykisk uro. Kortisolog ACTH-verdier var stigende til henholdsvis rundt $900 \mathrm{nmol} / \mathrm{log} 22 \mathrm{pmol} / \mathrm{l}$ både morgen og kveld. Kortisol i spytt kveld og kortisol i døgnurin var begge sterkt forhøyet.

På bakgrunn av tidligere sykehistorie, der vi hadde konkludert med en fysiologisk forbigående kortisoløkning, avventet vi oppstart av medikamenter rettet mot kortisoloverproduksjon og planla snarlig endoskopisk ultralydundersøkelse og finnålsaspirasjonscytologi av lungetumor.

Pasienten utviklet i mellomtiden magesmerter og utspilt buk. Grunnet respirasjonsbesvcer ble han lagt på intensivpost med respirasjonsstøtte. Endoskopisk ultralydundersøkelse måtte utsettes, men man gjorde ny FDG-PET/CT fire år etter siste undersøkelse. Denne gangen var det økt FDG-opptak basalt i venstre underlappstumor (figur 3 ).

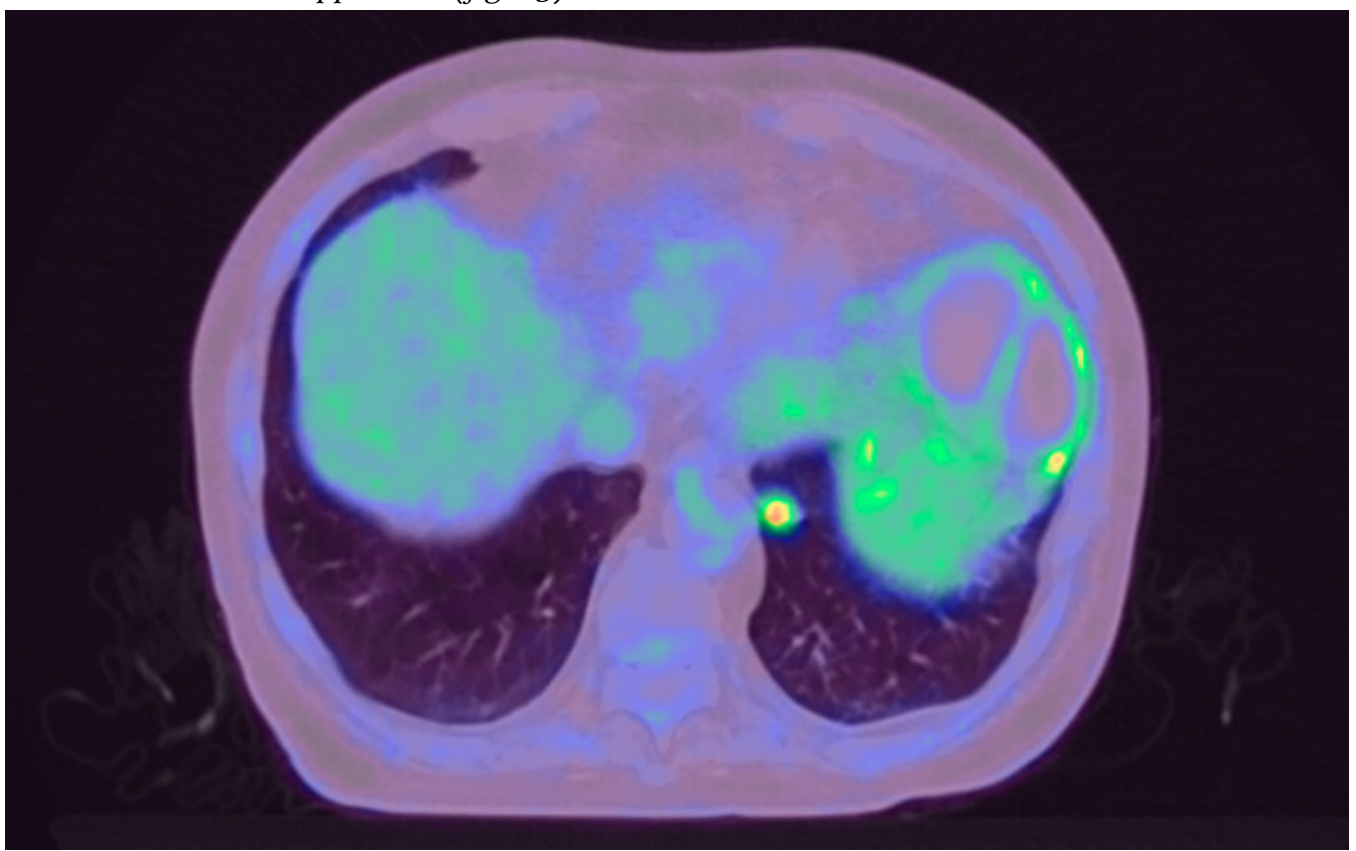

Figur $3 \emptyset \mathrm{kt} \mathrm{FDG-opptak} \mathrm{i} \mathrm{tumor} \mathrm{medialt} \mathrm{og} \mathrm{basalt} \mathrm{i} \mathrm{venstre} \mathrm{lunges} \mathrm{underlapp} \mathrm{ved} \mathrm{FDG-}$ PET/CT tatt under siste innleggelse.

CT abdomen viste funn forenlig med akutt nekrotiserende pankreatitt. Pasienten ble ansett som inoperabel grunnet komorbiditet og ble behandlet konservativt med drenasje og antibiotika. Hans kliniske tilstand forverret seg raskt, og han døde med pankreatitt og respirasjonssvikt.

Det ble utført obduksjon. Svarende til pankreas' anatomiske lokalisasjon og videre under diafragma på venstre side var det rikelig gråbrunt nekrotisk materiale. Det ble påvist sparsomt med bevart pankreasvev med spredte hvite stearinflekker som ved pankreatitt, med overgang til nekrotisk område forenlig med utbred nekrotiserende pankreatitt. Medialt i venstre lunges underlapp subpleuralt var det en $16 \mathrm{~mm}$ stor velavgrenset svulst. Svulsten var rødbrun med fast konsistens og homogen snittflate. Ved mikroskopisk undersøkelse var den kapselkledd og bestod av små celler 
voksende iflak, med moderat mengde cytoplasma og runde kjerner uten tydelig nukleol (figur 4). Det var svcert få mitoser og ingen sikker nekrose. Cellene i svulstvevet var positive for de nevroendokrine markørene $C_{5} 6$, synaptofysin og kromogranin $A$, mens tilstøtende lungevev var negativt.

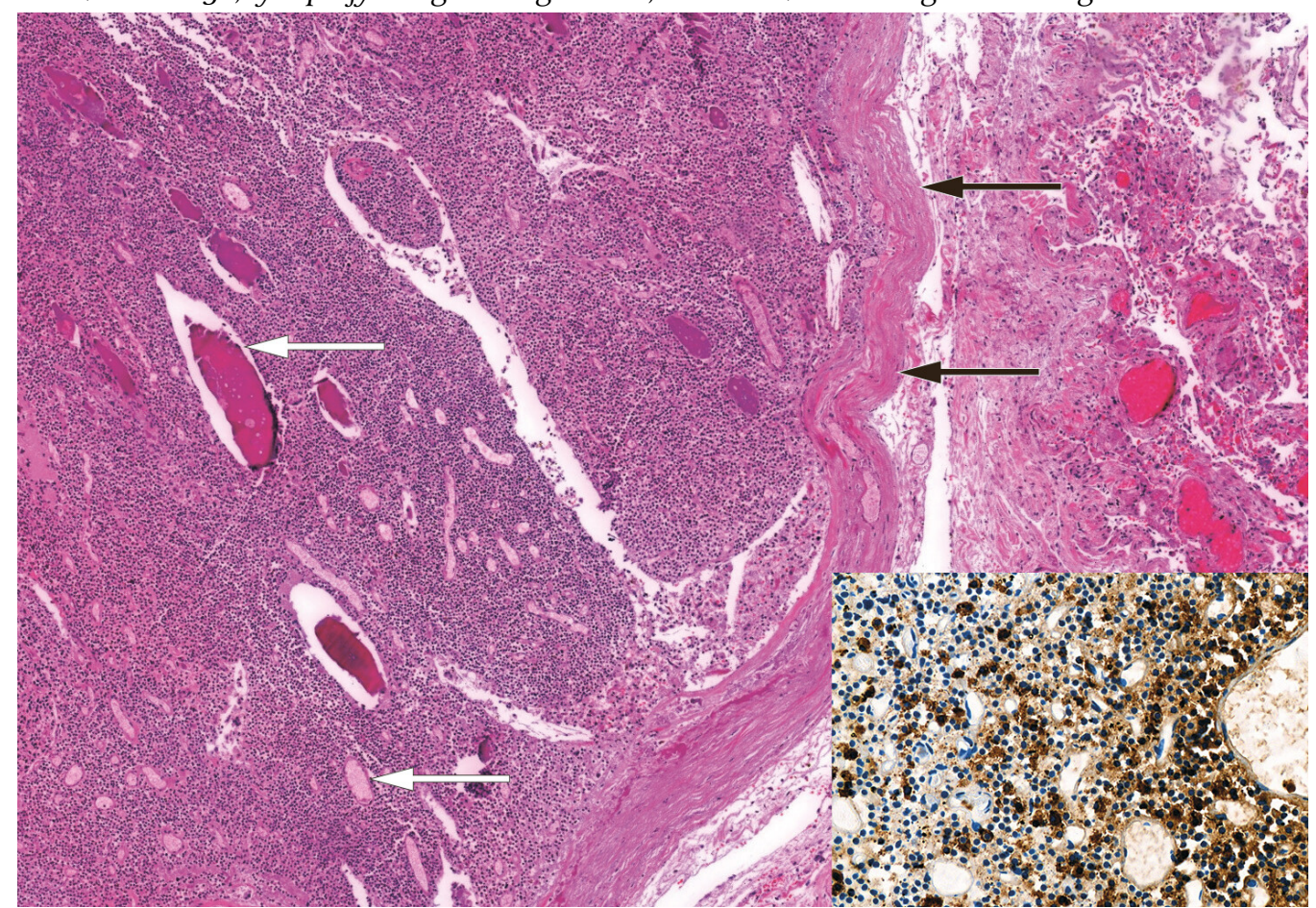

Figur 4 Hematoksylin- og eosinfarget histologisk snitt fra lunge ved obduksjon viser

lungevev med en velavgrenset, kapselkledd svulst (markert med sorte piler). Svulsten er rikt vaskularisert (blodkar markert med hvite piler). Svulstcellene vokser hovedsakelig i flak og er uniforme med moderat mengde cytoplasma og runde, mørke kjerner. Ved immunhistokjemisk undersøkelse var svulstcellene positive for nevroendokrine markører. Samlet var de histologiske funnene forenlig med lavgradig nevroendokrin svulst, såkalt karsinoid, i lunge. Det ble i tillegg utført immunhistokjemisk undersøkelse for adrenokortikotropt hormon (ACTH). Innfelt ses detalj fra immunhistokjemisk farget snitt som viser positivitet for ACTH i svulstcellene som fremkommer som brunfarge i cytoplasma.

Immunhistokjemisk farging for ACTH viste tydelig positivitet $i$ cytoplasma i svulstcellene. Betydningen av proliferasjonsmarkøren Ki67 i obduksjonsmaterialet er usikker, men det ble bemerket svcert lav Ki67 $i$ svulstvevet mens det forelå spredt positivitet $i$ tilstøtende lungevev, hovedsakelig $i$ områder med kronisk betennelse. Det histologiske bildet passet med lavgradig nevroendokrin tumor $i$ lunge, såkalt karsinoid, hvor funn av $<2$ mitoser per $2 \mathrm{~mm}^{2}$, Ki67 $\leq 5 \%$ og fravcer av nekrose er forenlig med typisk karsinoid (3). For øvrig var binyrene litt store og preget av autolyse, men med bevart overordnet arkitektur. Hypofysen var upåfallende og uten holdepunkt for adenom.

Samlet var klinisk utredning og funn ved obduksjonen forenlig med Cushings syndrom forårsaket av ektopisk ACTH-produksjon fra karsinoid tumor i lunge. Det kliniske forløpet kunne passe med syklisk Cushings syndrom (4).

\section{Diskusjon}

Diagnostikk av Cushings syndrom er utfordrende. Spesielt kan det være vanskelig å skille fysiologisk fra patologisk kortisolforhøyelse. Syklisk Cushings syndrom, hvor episoder med hyperkortisolisme avbrytes av perioder med normal kortisolsekresjon, er svært sjelden og byr på særlige diagnostiske utfordringer (4).

Flere faktorer bidro til at diagnosen i dette tilfellet ikke ble sikker før det var for sent. Pasienten ble klinisk og biokjemisk frisk etter at tynntarmsperforasjon og pankreatitt ble kirurgisk behandlet i første runde. Dette gjorde at vi oppfattet hans forbigående 
hyperkortisolisme til å ha vært en fysiologisk respons. Årsaken til sykdommen - en langsomtvoksende nevroendokrin tumor i lunge - ble ikke vektlagt nok tidlig i forløpet, da den var utseendemessig benign, og verken FDG-PET/CT, oktreotidscintigrafi eller cytologi ga initialt mistanke om malignitet.

De to første FDG-PET/CT-undersøkelsene kunne imidlertid gi grunn til mistanke om både falskt positive og falskt negative funn, da første undersøkelse ble tatt for tidlig etter prøvetaking av tumor og andre med forhøyet blodsukker. Oktreotidscintigrafi kan også underestimere opptak for nevroendokrine tumorer under $2 \mathrm{~cm}$. Vi burde derfor lagt mer vekt på å få avklart lungeforandringen tidligere i forløpet, helst med perkutan lungebiopsi etter at den første finnålsaspirasjonscytologien fra lungetumor ikke ga konklusiv diagnose. Ved klinisk funn av hyperkortisolisme kan ikke én enkelt negativ cytologisk prøvetaking tillegges avgjørende vekt.

Ved symptomresidiv medførte interkurrent sykdom samt oppfølging av andre funn at ny prøvetaking stadig ble utsatt. I dag er PET/CT med ${ }^{68}$ Ga-DOTATOC et alternativ $\mathrm{i}$ utredningen. Denne er mer følsom for nevroendokrine tumorer med lav Ki67 enn FDGPET/CT (5) (ramme 2).

\section{Ramme 2 Bildediagnostikk ved mistanke om nevroendokrin tumor i lunge} (3).

- FDG-PET/CT er anbefalt hos alle pasienter med lungekreft som er aktuelle for kurativ behandling.

- Nevroendokrine tumorer kan ha varierende opptak ved FDG-PET/CT.

- Nevroendokrine tumorer uttrykker oftest somatostatinreseptorer og anbefales utredet med somatostatinreseptorbasert bildediagnostikk, som oktreotidscintigrafi eller PET/CT med 68Ga-DOTATOC.

- PET/CT med 68Ga-DOTATOC foretrekkes foran oktreotidscintigrafi grunnet bedre sensitivitet.

- Typiske karsinoide tumorer har lav proliferasjonsaktivitet (Ki67-indeks) og høy somatostatinreseptoruttrykk og avbildes godt ved somatostatinreseptorbasert bildediagnostikk.

- Atypiske karsinoide tumorer har ofte høyere proliferasjonsaktivitet (Ki67-indeks) og lavere somatostatinreseptoruttrykk og avbildes da vanligvis med høyere opptak ved FDG-PET/CT.

Behandlingsmessig valgte vi å ikke sette inn kortisolsenkende behandling under andre sykdomsperiode. Dette var begrunnet med sterk mistanke om at kortisolstigningen var sekundær til underliggende pankreatitt - og ikke motsatt - og man var redd for å utløse en relativ binyresvikt. I ettertid er det lett å tenke at vi burde ha startet med eksempelvis metyrapon kombinert med kortikosteroidsubstitusjon basert på klinisk respons. Bilateral adrenalektomi for rask sykdomskontroll kan også vurderes, men var ikke aktuelt i dette tilfellet, hvor man måtte avstå fra kirurgi grunnet komorbiditet.

I stedet for vår initiale tolkning, at kortisoløkningen kom sekundært til pankreatitt, kan man undres på om pasientens pankreatitter var utløst av de høye kortisolnivåene. I en kasus-kontroll-studie fant man $\emptyset \mathrm{kt}$ risiko for akutt pankreatitt hos brukere av perorale glukokortikoider (OR 1,53, 95 \% konfidensintervall 1,27-1,84) (ㅁ). Likedan er det rapportert tilfeller hvor pasienter fikk pankreatitt etter oppstart med perorale steroider - ikke bare én gang, men også ved reeksponering (7,, $)$.

Dette sykdomsforløpet var langvarig og krevende og endte dessverre fatalt. Pasientens pårørende har et ønske om at man drar lærdom av denne historien, som demonstrerer at man ikke skal undervurdere det nevroendokrine potensialet til tilsynelatende uskyldige 
lungetumorer. Den viser også at forløpet til syklisk Cushings syndrom kan være svært langtrukkent. I tillegg stiller avanserte diagnostiske prosedyrer store krav til kommunikasjon om potensielle feilkilder og feiltolkninger.

Pasientens ektefelle har samtykket til at artikkelen blir publisert.

Takk til overlege Trond Bogsrud ved Nuklecermedisinsk avdeling, Oslo universitetssykehus, for faglige innspill og tilrettelegging av nuklecermedisinske bilder. Takk også til Bildediagnostisk avdeling, Akershus universitetssykehus for bruk av CT-bilde (figur 2).

Artikkelen er fagfellevurdert.

\section{LITTERATUR}

1. Jørgensen AP, Tazmini K. red. Nasjonal veileder i endokrinologi. www.endokrinologi.no Lest 19.5.2020.

2. Fliers E, Bianco AC, Langouche L et al. Thyroid function in critically ill patients. Lancet Diabetes Endocrinol 2015; 3: 816-25. [PubMed][CrossRef]

3. Helsedirektoratet. Nasjonalt handlingsprogram med retningslinjer for diagnostikk, behandling og oppfølging av lungekreft, mesoteliom og thymom.

https://www.helsedirektoratet.no/retningslinjer/lungekreft-mesoteliom-og-thymomhandlingsprogram Lest 19.5.2020.

4. Meinardi JR, Wolffenbuttel BH, Dullaart RP. Cyclic Cushing's syndrome: a clinical challenge. Eur J Endocrinol 2007; 157: 245-54. [PubMed][CrossRef]

5. Isidori AM, Sbardella E, Zatelli MC et al. Conventional and nuclear medicine imaging in ectopic Cushing's syndrome: a systematic review. J Clin Endocrinol Metab 2015; 100:3231-44. [PubMed] [CrossRef]

6. Sadr-Azodi O, Mattsson F, Bexlius TS et al. Association of oral glucocorticoid use with an increased risk of acute pancreatitis: a population-based nested case-control study. JAMA Intern Med 2013; 173: 444-9. [PubMed][CrossRef]

7. Levine RA, McGuire RF. Corticosteroid-induced pancreatitis: a case report demonstrating recurrence with rechallenge. Am J Gastroenterol 1988; 83: 1161-4. [PubMed]

8. Felig DM, Topazian M. Corticosteroid-induced pancreatitis. Ann Intern Med 1996; 124: 1016. [PubMed][CrossRef]

Publisert: 28. august 2020. Tidsskr Nor Legeforen. DOI: 10.4045/tidsskr.19.0751

Mottatt 19.11.2019, første revisjon innsendt 1.4.2020, godkjent 19.5.2020.

(C) Tidsskrift for Den norske legeforening 2023. Lastet ned fra tidsskriftet.no 26. april 2023. 